\title{
Method or Madness? Sociolatry in International Thought
}

\section{PATRICIA OWENS*}

\begin{abstract}
International theory has a social problem. Twenty years after the so-called 'social turn', the historical origins of distinctly social forms of thought are not subject to scrutiny, let alone well understood. Indeed, the problem of the ahistorical social is an issue not only for predominant liberal, realist, and constructivist appropriations of social theory, but also the broad spectrum of critical and Marxist modes of theorising. In contrast to practicing sociolarty, the worship of things 'socio', this article addresses the historicity of the social as both a mode of thought - primarily in social theories and sociology - against the background of the emergence of the social realm as a concrete historical formation. It highlights problems with the social theoretic underpinnings of liberalism, social constructivism, and Marxism and advances an original claim for why the rise of the social was accompanied by attacks on things understood (often erroneously) as political. To fully understand these phenomena demands a closer examination of the more fundamental governance form the modern social realm was purported to replace, but which it scaled up and transformed.
\end{abstract}

Patricia Owens is Reader in International Relations at the University of Sussex. She is author of Economy of Force: Counterinsurgency and the Historical Rise of the Social (Cambridge, 2015) and Between War and Politics: International Relations and the thought of Hannah Arendt (Oxford, 2007). She has held research fellowships at Harvard, Princeton, UC-Berkeley, USC, and Oxford and is currently a co-editor of European Journal of International Relations.

Thou shalt not answer questionnaires

Or quizzes upon World-Affairs,

Nor with compliance

Take any test. Thou shalt not sit

With statisticians nor commit

A social science

W. H. Auden

A severe sociomania afflicts international theory. Consider the sway of social language in the field. The "voice of social theory" grounds the work of social constructivists, neoliberal institutionalists, scholars of international society, Weberian and Marxist historical sociologists, international political sociologists, structural realists, Foucaultians, and philosophers of social science. These traditions variously take as axiomatic the reality of underlying social forces, social facts, social systems, social structures, social norms, social processes, socialisation, international society, global civil society and so on. The instinctive adoption of social languages is indicated in the episodic discussion of whether International Relations (IR) is an American social science. ${ }^{2}$ Debate has focused

$1 *$ Research for this article was supported by a year long Fellowship at the Radcliffe Institute for Advanced Study, Harvard University. For comments on earlier drafts, I am grateful to three anonymous reviewers and co-panellists and audience members at the 2012 and 2013 ISA Annual Conventions and during

presentations at the LSE, Oxford, Aberystwyth, Westminster, City University, Sussex, and Harvard. Justin Rosenberg, 'Why is there no International Historical Sociology?' European Journal of International Relations, Vol.12, no.3 (2006), p.335

2 Stanley Hoffmann, 'An American Social Science: International Relations', Daedalus, Vol.106, no.3

(1977), pp.41-60 
entirely on the words American and science. In the opening editorial statement of the journal International Political Sociology the authority of socio-historical and sociopolitical analyses is unquestioned. ${ }^{3}$ As George Lawson and Robbie Shilliam have put it, "there is relatively little in the discipline - at least in terms of IR theory - that stands outside from the influence of sociological approaches, theories and concepts' ${ }^{4}$ Yet when did sociological explanations for human affairs first emerge and why? Perhaps the international historical sociologists could respond. However, these would-be historians fair little better than the theorists, liberally but a-historically evoking terms such as social process, social structure, social matrices, social norms, social logic, social contexts, social forces, social world, and social organisation. ${ }^{5}$ To date, international historical sociology is far more sociological than historical. It is excited about the intellectual possibilities of things 'socio', but has ignored the historical origins of distinctly social theorising, of when and why sociological explanations for human affairs first emerged and what this history might reveal.

The impression that human affairs require 'social' explanations is relatively new. Until the eighteenth-century, the term social, from the Latin socius, simply meant companion or gathering, to be friendly or genial. 'As late as 1694', writes Daniel Gordon, 'when the first edition of the Dictionnaire de l-Académie Française appeared, it was possible to define société without evoking in any way the concept of a general field of human existence'. ${ }^{6}$ When did it become possible to conceive of specifically social relations as a general field of human interaction on which everything else was based, the notion that social forces underpin all other institutions of human life? When, in other words, was the first social turn? Surprisingly, almost twenty years after such a "turn" ${ }^{7}$ in IR, it is rather difficult to find an answer to this question in international studies. The historical origins of distinctly social forms of thought are not subject to scrutiny, let alone well understood. Instead, the role of sociological categories in IR is usually presented in terms associated with the philosophy of social science or as a belated effort at interdisciplinary scholarship, perhaps an effort to beg, borrow, and steal ideas from sociology to add intellectual depth to a 'failed intellectual project'. ${ }^{8}$ In social constructivism, for example, the idealist and holist advance over the materialist, rationalist, and individualist assumptions of neorealism and neoliberalism is a philosophical issue, one made possible by the 'second order' questions of social theory. For the philosophers of science, social theories allow the leading political theories of

\footnotetext{
3 Didier Bigo and R. B. J. Walker, 'International, Political, Sociology', International Political Sociology, Vol.1, no.1 (2007), p.1

4 George Lawson and Robbie Shilliam 'Sociology and International Relations: Legacies and Prospects', Cambridge Review of International Affairs, Vol.23, no.1 (2010), p.71. C.f. 'sociology and social theory... have so far played only a marginal role in the development of international relations'. Bigo and Walker, 'International', p.1.

5 These terms are taken from George Lawson and John M. Hobson, 'What is History in International Relations?' Millennium: Journal of International Studies, Vol.37, no.2 (2008), pp.415-435

6 Daniel Gordon, Citizens without Sovereignty: Equality and Sociability in French Thought, 1670-1789 (Princeton, NJ: Princeton University Press, 1994), p.51

7 Martin Weber, 'The Critical Social Theory of the Frankfurt School, and the "Social Turn" in IR', Review of International Studies, Vol.31, no.1 (2005), pp.195-209

8 Barry Buzan and Richard Little, 'Why International Relations has Failed as an Intellectual Project', Millennium: Journal of International Studies, Vol.30, no.1 (2001), pp.19-39
} 
international relations - liberalism, political realism, Marxism - to be more explicit about epistemology and ontology, 'about what kinds of things are to be found in international life, how they are related, and how they can be known'. ${ }^{9}$ Second order questions are more fundamental, deeper, than the competing political theories of international politics.

This methodological and philosophical rationale for developing distinctly social theories of international politics reflects the original claims on behalf of the new social philosophy that emerged toward the end of the eighteenth-century. As recounted in sociology textbooks, the early modern scientific revolution - in which religious superstition was replaced by reason - logically extended to explanations for human affairs more generally. 'Society', not God, was 'discovered' as the 'really real'. ${ }^{10}$ The secularisation of thought underpinning enlightenment philosophy placed human action and institutions at the centre of new theories about what civilised humans could achieve. Crucially, however, the first and foremost celebrants of the autonomous logic of society, of raison de la société, were European theorists of bourgeois 'civilised society' and its forms of commercial sociability. ${ }^{11}$ This seeming discovery that the world was "socially constructed' by the interactions of humans in society would be shared by all the major figures of classical social theory. For by the middle of the nineteenth-century, Karl Marx had abandoned the bourgeois abstractions of the autonomous individual in civil society but nonetheless embraced and further pioneered the new hegemonic 'social' discourse to develop a philosophy of history and critique of capitalism centring on social being. The two other leading founders of sociology, Max Weber and Emile Durkheim, challenged Marx's emphasis on the mode of production, but further pioneered distinctly sociological theories of the sovereign state and liberal solidarity. Sociology, tautologically, was the study of society or social relations, the 'analysis of what... social actors do' ${ }^{12}$ Classical social theory presents itself as based on this methodological discovery of society and things 'social' as the really real. Social, society, and their cognate terms became the scientific categories to describe all human relations as self-instituted in light of the secular relational constitution of the human world: social actors, socially constructing their social world. ${ }^{13}$ By the beginning of the twentieth-century, political realists, liberals, and Marxists all agreed that social forces were the underlying causes of what appeared in

9 Alexander Wendt, Social Theory of International Politics (Cambridge: Cambridge University Press, 1999), p.5

10 Randall Collins and Michael Makowsky, The Discovery of Society (New York, Random House, 1972); Geoffrey Hawthorn, Enlightenment and Despair: a History of Sociology (Cambridge: Cambridge University Press, 1977); John D. Greenwood (ed.) The Mark of the Social: Discovery or Invention? (Lanham: Rowman \& Littlefield Publishers, 1977); Tom Bottomore and Robert Nisbet (eds.) A History of Sociological Analysis (Portsmouth, NH: Heinemann, 1979); E. J. Hundert, The Enlightenment's Fable: Bernard Mandeville and the Discovery of Society (Cambridge: Cambridge University Press, 1994); Allen Swingewood, A Short History of Sociological Thought ( $3^{\text {rd }}$ edition) (London: Palgrave, 2000); Lewis A. Coser, Masters of Sociological Thought: Ideas in Historical and Social Context ( $2^{\text {nd }}$ edition) (Long Grove, Il: Waveland Press, 2003)

11 Kenneth Michael Baker 'Enlightenment and the Institution of Society: Notes for a Conceptual History' in Willem Melching and Wyger Velema (eds.) Main Trends in Cultural History: Ten Essays (Amsterdam: Rodopi, 1994), pp.95-120

12 Bigo and Walker, 'International', p.4

13 Peter Wagner, “'An Entirely New Object of Consciousness, of Volition, of Thought': The Coming into Being and (Almost) Passing Away of "Society" as a Scientific Object' in Lorraine Daston (ed.)

Biographies of Scientific Objects (Chicago: University of Chicago Press, 2000), pp.132-157 
the world. Different international theories simply debated which were the most important: conflict groups, classes, or domestic liberal norms. ${ }^{14}$ Without doubt, each of the main traditions of international theory is currently deeply beholden to distinctly social theories and concepts. Indeed, it is no exaggeration to say that international theory currently exhibits sociolatry, the worship of things 'socio'. As Auguste Comte wrote in System of Positive Polity or Treatise on Sociology: Instituting the Religion of Humanity, sociolatrie was to be the 'ideal embodiment of Sociology'. ${ }^{15}$

What were the national, international, and imperial origins of the most influential social theories from which contemporary international theory develops? What was the historical context for the emergence of distinctly social thought and why does it matter for the story told in IR about methodological advance? International theory cannot begin to answer these questions if it remains in the realm of the philosophy of social science; if it ignores the historicity of its theoretical categories; if accepts the tautology that sociology is the study of what 'social actors do'; and if it presumes that social theories are the only or true heirs of the secular relational constitution of the human world. International studies, like other social sciences more generally, has not paid sufficient attention to the rootedness of the history and theory of the social and society in a very particular context and location nor begun to ask what this history means for attempts to incorporate social thought into the field. In contrast, this article argues that instead of practicing sociolatry or 'sociologism', ${ }^{16}$ international theory needs first to address the historicity of the social as both a mode of thought - primarily in social theories and sociology - against the background of the emergence of the social realm as a concrete historical formation. If the new social discourses were not simply discovered during the French and Scottish Enlightenments, but emerged in a very specific context for definite purposes, then the philosophy of science narrative would need to be subsumed inside an approach that was potentially more problematic and demanding for international theory: it would involve explicit discussions of history and politics. ${ }^{17}$

The most important setting for the rise of social theory is the new meanings and set of distinctions between 'government' and 'economy' that accompanied the rise of modern capitalist states/empires in the eighteenth-century. Specifically, a new social philosophy was a product of efforts to understand and justify the rise of commercial sociability and its bourgeois 'civil society'. By the nineteenth-century, much more concerted and largely state-led efforts to demobilise recently mobilised and unruly populations (including in the colonies) were accompanied by new sociological discourses

14 Kenneth N. Waltz, Theory of International Politics (Reading, MA: Addison-Wesley, 1979); Robert Cox, 'Social Forces, States and World Orders: Beyond International Relations Theory' in Robert Keohane (ed.) Neorealism and its Critics (Princeton: Princeton University Press, 1986), pp.204-254; Robert O.

Keohane and Joseph Nye, Power and Interdependence (New York: Harper Collins, 1989); Nicholas Onuf, Worlds of Our Making: Rules and Rule in Social Theory and International Relations (Columbia, SC: University of South Carolina Press, 1989)

15 Auguste Comte, System of Positive Polity or Treatise on Sociology: Instituting the Religion of Humanity (London: Longmans, Green and co., 1875), p.116

16 Sociologism is the belief that "sociology should become the new queen of the sciences of man, the magistra of philosophy, ethics, historiography, jurisprudence, political science, art theory, and the like. Jerzy Szacki, History of Sociological Thought (London: Aldwych, 1979), p.278

17 The point is not to suggest that there is only one form of enlightenment thought, rather that claims about the 'discovery' of society are based on a particular reading of the enlightenment. See Baker 'Enlightenment and the Institution of Society' 
and practices - socialisation, social norms, traditional society, social policy, social insurance - explicitly seeking non-political explanations and remedies for violent revolts. The social theories now dominant in international theory emerged in this period - the Age of the Social - in the context of class and imperial crises-driven transformations of the social realm. The very notion of 'socialisation', so influential in contemporary international theory, was a product of a political and ideological crisis in liberal capitalist governance. Surveying the historical rise of sociological thought we find that the hegemony of social theory was achieved against various forms of what was understood (sometimes erroneously) as 'political'. ${ }^{18} \mathrm{We}$ also find that the problem of the ahistorical social in international theory is an issue not only for predominant liberal, realist, and constructivist appropriations of social theory, but also the broad spectrum of critical and Marxist modes of theorising.

The article is divided into three sections, each highlighting a different problem with the social theoretic underpinnings of leading international theories: liberalism, social constructivism, and Marxism. ${ }^{19}$ The first part analyses the 'liberal' origins of distinctly social thought to identify the earliest claims on behalf of Raison de la Société with the eighteenth-century rise of the social realm. The civil society discourse that emerged in this period culminates in liberal internationalism's conception of societal interests and institutions, the product of the interactions of private individuals and groups. The second part examines the further 'socialisation' of liberalism in the nineteenth-century. We find that the most important origin of social constructivism is less as a critique of rational choice theory than the nineteenth-century rise of socio-biological theories of 'norms', a term adopted from biology, and theories of 'socialisation' to assist in the containment of disruptive and potentially revolutionary transformations of capitalist and imperial order. This is illustrated through analysis of George Herbert Mead's Progressive Era theory of symbolic interactionism so influential in constructivism. Given the intellectual hegemony

18 This article is the first effort to address the consequences of the historicity of social thought for international theory. For earlier analyses of different empirical domains see Patricia Owens, Economy of Force: Counterinsurgency and the Historical Rise of the Social (Cambridge: Cambridge University Press, 2015); Owens, 'From Bismarck to Petraeus: The Question of the Social and the Social Question in Counterinsurgency', European Journal of International Relations, Vol.19, no.1 (2013), pp.135-157; Owens, 'Human Security and the Rise of the Social', Review of International Studies, Vol.38, no.3 (2012), pp. 547-567; Owens, 'The Supreme Social Concept: The Un-worldliness of Modern Security', New Formations, no.71 (2011) pp.14-29.

19 Due to lack of space, we cannot address the relationship between Realpolitik and the rise of Sozialpolitik. Suffice-to-say that modern political realism represents a primarily German reassertion of the autonomy of the so-called 'political' (state) domain against French and Scottish Enlightenment claims of the autonomy of society. See George Steinmetz, Regulating the Social: the Welfare State and Local Politics in Imperial Germany (Princeton: Princeton University Press, 1993) and Owens, 'From Bismarck to Petraeus'. We also cannot address Foucaultian work in any detail. However, this other dominant tradition of critical international theory also freely draws on Foucault's assumed 'analytics of the social sphere' or his account of 'political society'. See Jef Huysmans, 'The Jargon of Exception - On Schmitt, Agamben and the Absence of Political Society', International Political Sociology, Vol.2, no.2 (2008) pp.165-183 and Vivienne Jabri, 'Michel Foucault's Analytics of War: the Social, the International, and the Racial', International Political Sociology, Vol.1, no.1 (2007) pp.67-81. These sociological readings of Foucault are dominant in IR, even though Foucault himself and many of his followers outside this field have been more circumspect about social language and more attentive to the historical conditions of its emergence. See Jacques Donzelot, L'invention du Social: Essai sur le déclin des Passions Politiques (Paris: Fayard, 1984) and Giles Deleuze, 'Foreword: The Rise of the Social' in Jacques Donzelot, The Policing of Families: Welfare versus the State (London: Hutchinson, 1979), pp.ix-xvii; Owens, 'Human Security'. 
of social terminology and its embrace by many nineteenth-century revolutionaries, social language would continue to expand; it was appropriated, reformed, and turned against some (but not all) aspects of civil society. Hence, the third section analyses Marxism, the strongest retort to the bourgeois logic of the earliest social philosophy. We find that Marx too readily adopted social modes of thought, with enduring consequences for critical political and international theory. The conclusion advances an original claim for why the material and intellectual rise of the social was always accompanied by attacks on something understood as political. To fully understand these recurring attacks demands a closer examination of what the arrival of social forms of governance and thought purported to replace, but which it scaled up and transformed. Ultimately, in adopting social language international theory has been unable to properly address the more fundamental governance form of which the modern social is a concrete historical expression.

\section{Liberalism and the Rise of Raison de la Société}

The global expansion of commerce in the eighteenth-century produced a new set of material and ideological distinctions between state-administrative (public) power and (privatised) economy. ${ }^{20}$ 'Public power', as Habermas describes, increasingly 'concentrated in national and territorial states, rose above a privatized society... The "social" could be constituted as its own sphere to the degree that on the one hand the reproduction of life took on private forms, while on the other hand the private realm as a whole assumed public relevance' ${ }^{21}$ In the most powerful commercial empires, the social realm emerged as the hybrid intermediary space between capitalist economy and statepolitical institutions; a product of the newly constituted, newly separated, spheres of public and private attendant the rise of capitalism and administrative states. Commodity exchange 'burst out of the confines of the [feudal] household' ${ }^{22}$ and a new 'societal' theory of government emerged. In Withington's words, "household" and "family" figured much less frequently in the printed horizons of readers... This contrasts with the increasing visibility in print of "society" and "company" and the concept of deliberate and purposeful association they invoked'. ${ }^{23}$ The earliest and most influential attempts to theorise the new sphere of private exchange as distinct and autonomous from despotic power became the most influential models of a more general form of sociable interaction.

Seventeenth-century natural law theorists Hugo Grotius and Samuel Pufendorf did not have a concept of society as the ontological basis of all forms of human organisation. As discussed by Jens Bartelson in this Forum, while many have placed 'international society' writing within a 'Grotian tradition', Grotius had no conception of

20 See, for example, Max Weber, Economy and Society: an Outline of Interpretative Sociology, Vol.1 (ed. Guenther Roth and Claus Wittich) (Berkeley, CA: University of California Press, 1978) and Michael McKeon, The Secret History of Domesticity: Public, Private and the Division of Knowledge (Baltimore, MD: Johns Hopkins University Press, 2005)

21 Jürgen Habermas, The Structural Transformation of the Public Sphere: an Inquiry into a Category of Bourgeois Society (Cambridge, MA: MIT Press, [1962] 1991), p.127; Hannah Arendt, The Human Condition (Chicago: University of Chicago Press, 1958), part II, ch.6; Owens, Economy of Force.

22 Habermas, The Structural Transformation, p.28

23 Phil Withington, Society in Early Modern England: the Vernacular Origins of some Powerful Ideas (Cambridge: Polity, 2010), p.112 
society that corresponds to that used by the English School. ${ }^{24}$ Nonetheless, Grotius and Pufendorf extended the classical Roman use of societas - friendliness or partnership - to a principle of interaction - sociability - they defined as wholly distinct from the authoritarian state. The purest expression of this sociability was commerce for mutual advantage. For early modern theorists of natural law, commerce and sociability were inseparable. As Amalia Kessler has pointed out, Pufendorf took the prevailing definition of commercial partnership 'as his definition of civil society. Both... are contracts of association whereby the parties agree to promote the interests of the association above their own and to share all profits and losses'. ${ }^{25}$ Corresponding to a global expansion of commercial empires, thus emerged a new discourse centring on the forms of fellowfeeling that were taken to unite individuals within Europe's wider commercial associations outside the regulation of despotic power. Such claims were the context for John Locke's revolutionary theory of property and labour and Kant's writing on perpetual peace. ${ }^{26}$ For Locke, the right to own property did not originate in the discretion of kings but in the 'state of nature' prior to the founding of any civil government. ${ }^{27}$ Commercial society was governed through contract, the antithesis of governance in non-contractual, patriarchal households. However, even with these early 'societal' theories of property and republicanism, both Locke and Kant still used the language of 'political or civil society' to refer to state government, not as a general field of human interaction.

This came with the discourse of bourgeois civil society and its assault on the mercantilist ideology of Polizeistaats in which the state was imagined to rule over and administer its territory on the model of a well-ordered household. ${ }^{28}$ Building on early modern sociability discourses and Locke's theory of property, Montesquieu distinguished between the state's superior yet brutalising use of force and the more gentle mores of 'commercial society' contributing to a revaluation of the traditional distinctions between forms of government. ${ }^{29}$ The opposition between democracy, republic, monarchy, and

24 Jens Bartelson, 'Towards a Genealogy of 'Society' in International Relations', Review of International Studies (2015) 41:5, pp. [add at proof stage] In Bull's 'English School' definition, a society 'exists when a group of states, conscious of certain common interests and common values, form a society in the sense that they conceive themselves to be bound by a common set of rules in their relations with one another, and share in the working of common institutions'. Hedley Bull, The Anarchical Society: a Study of Order in World Politics (London: Macmillan, 1977) p.13; also see Hedley Bull, 'The Grotian Conception of International Society' in Herbert Butterfield and Martin Wight (eds.) Diplomatic Investigations: Essays in the Theory of International Politics (London: Allen \& Unwin, 1966), pp.51-73. This 'definition' of society derives from Durkheim's attempt to offer a sociological - rather than political - explanation for the violent and extreme disorder of the Third Republic.

25 Amalia D. Kessler, A Revolution in Commerce: the Parisian Merchant Court and the Rise of Commercial Society in Eighteenth-Century France (New Haven, CT: Yale University Press, 2007), p.158

26 “"Asocial sociability”, in Doyle's influential interpretation of Kant's idea, 'draws men together to fulfill needs for security and material welfare as it drives them into conflicts over the distribution and control of social [sic] products. This violent natural evolution tends towards the liberal peace because "asocial sociability" inevitably leads toward republican governments, and republican governments are a source of liberal peace'. Michael W. Doyle, 'Liberalism and World Politics', The American Political Science Review, Vol.80, no.4 (1986), p.1160

27 John Locke, Two Treaties of Government (with Introduction and notes by Peter Laslett) (Cambridge: Cambridge University Press, [1689] 1963)

28 Markus Dirk Dubber, The Police Power: Patriarchy and the Foundations of American Government (New York: Columbia University Press, 2005)

29 Charles de Secondat Montesquieu, The Spirit of the Laws (trans. and ed. Cohler, Anne M., Basia C. 
aristocracy was succeeded with one between civilised and uncivilised regimes. The degree of civility was determined by protections on private property and polite sociétés where the manners most suited to commerce were instilled. In fact, Montesquieu still did not use the term social to describe human relationships or institutions. Yet Hume and Smith wrote of 'society' as an aggregation of self-interested individuals related to each other by bonds of envy and competition. ${ }^{30}$ Again, ideas related to the expansion of commerce allowed enlightenment thinkers to conceive a wider society as self-instituting, advancing the much stronger notion of an autonomous societal logic. In opposition to absolutist claims that order and peace were only possible under sovereign protection, modes of sociability practiced in philosophical societies and salons underpinned claims that polished, civilised, individuals could self-police. ${ }^{31}$ For when society had progressed to its polite form continual and open despotic control was unnecessary. Political rhetoric in the ancien régime was clearly a sham; more authentic 'private' discussion was exalted. Specifically, ideals expressed in the self-consciously non-political polite conversation of the salons were extended to the public domain; 'société stood for the framework of human existence, sociabilité designated the desire of humans to participate in société, and sociable and social referred to the personal qualities and virtuous actions that sustained société'. ${ }^{32}$

Sociability discourse was not a full-blown critique of the state, a denial of the necessity of control over violence, sovereignty in foreign affairs, and collection of the necessary revenues: justice, peace, revenue and arms. ${ }^{33}$ Rather it was a claim that another mode of sociable interaction was possible, creating a space in-between absolute hierarchy and equality. To borrow influential IR language, individual 'preferences were taken seriously' without erupting into anarchy and disorder. ${ }^{34}$ The opposition between sovereignty and anarchy was dissolved in sociability discourse, eventually forming the international theory language of a 'society of states'. ${ }^{35}$ If eighteenth-century European state system was viewed as a 'system of multiple interactive parts', then this was underpinned by new ideas regarding society as an organic interdependent whole. ${ }^{36}$

Miller and Harold S. Stone) (Cambridge: Cambridge University Press, [1748] 1989)

30 David Hume, A Treatise on Human Nature, Volume 2 (Rockville MD: Wildside Press LLC, [1738] 2007); Christopher J. Finlay, Hume's Social Philosophy: Human Nature and Commercial Sociability in A Treatise of Human Nature (New York: Continuum, 2007); Brian C.J. Singer, 'Montesquieu, Adam Smith and the Discovery of the Social', Journal of Classical Sociology, Vol.4 (2004), pp.31-57

31 The language of 'polished commercial nations' pervades Adam Ferguson, An Essay on the History of Civil Society (Cambridge: Cambridge University Press, [1767] 1995). As Koselleck put it, 'under the protection of the Absolutist State... the new society created its institutions, the tasks of which... were "social"'. Reinhart Koselleck, Critique and Crisis: Enlightenment and the Pathogenesis of Modern Society (Cambridge, MA: MIT Press, 1988 [1959]), p.66

32 Gordon, Citizens without Sovereignty, p.53; also see Norbert Elias, The Civilizing Process:

Sociogenetic and Psychogenetic Investigations (Oxford: Blackwell Publishers, 2000)

33 Adam Smith, Lectures on Justice, Peace, Revenue and Arms (Oxford: Clarendon Press [1763] 1896)

34 Andrew Moravcsik, 'Taking Preferences Seriously: a Liberal Theory of International Politics', International Organization, Vol.51, no.4, (1997), pp.513-553

35 Bull, Anarchical Society

36 Daniel H. Deudney, Bounding Power: Republican Security Theory from the Polis to the Global Village (Princeton: Princeton University Press, 2007). Contra Deudney, the 'republican' characteristics of eighteenth-century European polities was largely formulated through the new conceptual language of society. Indeed, modes and rituals of sociability were central to the transformation of, rather than 
Society was the deeper, underlying ground of government, production, and international/imperial relations. Theology and classical political philosophy could be demoted in favour of social philosophy because political institutions and laws were conceived as the products of underlying social (and private) conventions. ${ }^{37}$ Society was now the fundamental grounds of human existence; politics was relegated. As Moravcsik put it in a seminal statement of liberal internationalism, 'the demands of individuals and societal groups are treated as analytically prior to politics... Socially differentiated individuals define their material and ideational interests independently of politics... [S]ocial purposes [underlie] the strategic calculations of government'. ${ }^{38}$

Since the rise of distinctly social philosophy in the late eighteenth-century it has been difficult to argue against the proposition that politics was superstructure, a cosmetic, exterior indicator of something hidden - social structure - and thus an effect of something much more profound. Deeper developmental tendencies of social organisation were rooted in the underlying social base, the inner workings of the social organism. This was the beginning of social theory as tantamount to a theory of everything human, laying the groundwork for the extension of what was essentially a theory about the organisation of life processes to virtually every other sphere of life. In its most powerful earliest formulation the mores developed in the specific context of salons sociétés were understood to underpin specific moral principles and the 'social' - including colonial order at large. ${ }^{39}$ The polite interaction in the salons was the basis of universal morality, its etiquette enlarged to humanity as a whole. From histories of international thought we already know some of the connections between eighteenth-century sociability discourses on the theory and practice of early Benthamite imperialism; on notions of civilisation and barbarism in consolidating imperial hierarchy; the rise of a new sphere of argument in the salons and forms of global publicity; theories of liberal democratic peace; and new forms of comparative and global history. ${ }^{40}$ International studies seem less interested in what the

realisation, of earlier republican conceptions of political virtue into nascent liberal notions of the proper humane conduct of individuals in commercial society.

37 For excellent accounts see Johan Heilbron, The Rise of Social Theory (trans. Sheila Gogol) (Minneapolis: University of Minnesota Press, 1995); Sheldon Wolin, Politics and Vision: Continuity and Innovation in Western Political Thought (expanded edition) (Princeton: Princeton University Press, 2004); Jean Terrier, Visions of the Social: Society as a Political Project in France, 1750-1950 (Boston: Brill, 2011)

38 Moravcsik, 'Taking Preferences Seriously', p.513, 517

39 Gayan Prakash, 'The Colonial Genealogy of Society: Community and Political Modernity in India', in Patrick Joyce (ed.) The Social in Question: New Bearings in History and the Social Sciences (London: Routledge, 2002), pp.81-96; Sudipta Kaviraj and Sunil Khilnani (eds.) Civil Society: History and Possibilities (Cambridge: Cambridge University Press, 2001); Gurminder Bhambra, Rethinking Modernity: Postcolonialism and the Sociological Imagination (London: Palgrave, 2007)

40 See, variously, Torbjørn L. Knutsen, A History of International Relations Theory $\left(2^{\text {nd }}\right.$ edition) (Manchester: Manchester University Press, 1997), chapter 4; Edward Keene, International Political Thought: a Historical Introduction (Cambridge: Polity, 2005), chapters 5-6; Jennifer Pitts, A Turn to Empire: the rise of Imperial Liberalism in Britain and France (Princeton: Princeton University Press, 2005); Istvan Hont, 'The Language of Sociability and Commerce: Samuel Pufendorf and the Theoretical Foundations of the "Four Stages" Theory', in Jealousy of Trade: International Competition and the Nation-state in Historical Perspective (Cambridge, MA: Harvard University Press, 2005), pp.159-184; Habermas, Structural Transformation; Ronald Meek, Social Science and the Ignoble Savage (Cambridge: Cambridge University Press, 1976); Beate Jahn, The Cultural Construction of International Relations: the Invention of the State of Nature (London: Palgrave, 2000) 
rise of social theory re-presented, literally in the sense of depicting something in a different form. Before suggesting what this might be, we need to examine how reformist and revolutionary critics of civil society and sociability discourse adopted and transformed several of its characteristics.

\section{Social Quacks: Constructivists and Progressive Reformers}

It is not difficult to discern the class and civilisational/imperial interests articulated by the new social philosophy. By the middle of the nineteenth-century, the image of autonomous individuals rationally constructing a coherent and functioning civil society individuals self-regulating - was replaced by visions of society as far more fractious, in a state of violent mutiny, on the verge of revolution, and in need of major intervention. ${ }^{41}$ In response to a series of revolutionary upheavals across Europe and the colonies the social realm was transformed. ${ }^{42}$ The manifest contradictions between the democratic revolutions and the realties of life under industrial capitalism, the global expansion of capital and empire, laid bare the flaws of the earliest theories of civil society. In eighteenth-century sociability discourse, all those admitted into civil society were already civilised by definition. Outside society were primitives, serfs, pirates, and barbarians of varying kinds. By the nineteenth-century, nothing and nobody was external to what was now conceived of as a national or imperial society as a whole. Henceforth society only had margins to be integrated, populations that needed greater 'socialisation'. The modes of sociability and self-policing practiced in the polite societies were of little use in the face of proletarians and colonial peasants. The founders of sociology were in agreement. With the breakdown of feudal households and rise of the social realm new and differential forms of integration and solidarity for the masses would be required ${ }^{43}$ The crisis of order, viewed as a crisis of transition from feudal households to contract society, was encapsulated in the Social Question. ${ }^{44}$ How could order be maintained in the face of demands by the newly constituted masses, both industrial workers and colonial peasants in revolt?

Clearly, eighteenth-century sociability discourse was ill equipped to respond to

41 Peter Wagner, A Sociology of Modernity: Liberty and Discipline (London: Routledge, 1994); on the formative role of the 1847 Indian Mutiny on social theory see Karuna Mantena, 'Social theory in the Age of Empire' in Sankar Muthu (ed.) Empire and Modern Political Thought (Cambridge: Cambridge University Press, 2012), pp.324-350

42 Eric Hobsbawm, The Age of Revolution: Europe 1789-1848 (London: Weidenfeld and Nicolson, 1962); C.A. Bayly, The Birth of the Modern World, 1780-1914: Global Connections and Comparisons (Malden, MA: Blackwell, 2004); Barry Buzan and George Lawson, The Global Transformation: History, Modernity and the Making of Modern International Relations (Cambridge: Cambridge University Press, 2015)

43 Comte, System of Positive Polity; Sir Henry Sumner Maine, Village-Communities in the East and West (London: John Murray, 1876); Ferdinand Tönnies, Community and Association (London: Routledge and Kegan Paul, [1887] 1955); Émile Durkheim, The Division of Labour in Society (trans. W.D. Halls; intro. Lewis A. Coser) (New York: The Free Press, [1893] 1984); Otto Gierke, Natural Law and the Theory of Society, 1500-1800, Volume I (trans. with an introduction by Ernest Barker) (Cambridge: Cambridge University Press, 1934)

44 Robert Castel, From Manual Workers to Wage Laborers: Transformation of the Social Question (New Brunswick, NJ: Transaction Publishers, 2003); Philip Corrigan and Derek Sayer, 'The Working Class Question: "Society" and society', The Great Arch: English State Formation and Cultural Revolution (Oxford: Blackwell, 1985), chapter six; Steven Seidman, Liberalism and the Origins of European Social Theory (Berkeley, CA: University of California Press, 1983) 
the violent challenge of the Social Question. 'The ideal of sociability...' writes Gordon, 'did not provide the tools... needed to criticize a hyperpoliticized people'. ${ }^{45}$ Hence emerged the major European ideologies of the nineteenth-century: revolutionary and reformist socialists, conservatives and political realists, feminists, social liberals and supporters of laissez faire. Reformist social liberalism occupied the middle ground, advising 'the most multifarious social quacks, who, by all manners of tinkering professed to redress, without any danger to capital or profit, all sorts of social grievances'. ${ }^{46}$ This was, indeed, a 'middle ground' position, a 'via media', ${ }^{47}$ but less in terms of methodology than between laissez faire and revolution. In practice, grievances were 'redressed' through a combination of police repression and intensive social regulation of distinct segments of national and colonial populations. All the major European empires introduced protectionist and labour legislation, and then a series of state-led 'social policies' related to housing, health, crime, family and education, that is, interventions into the social milieu, another concept adopted from biology. In Karl Polanyi's influential account, the convergence across the major powers was an effort to rebalance market forces in favour of the general needs of 'society as a whole'. ${ }^{48}$ This position would become influential in liberal international theory where domestic and international markets are 'embedded' in local compromises. ${ }^{49}$ On this view, laissez faire was moderated because, through democratic means, 'societal preferences concerning the nature and level of regulation impose legitimate limits on markets'. ${ }^{50}$ In fact, state intervention was necessary to contain the threat of insurrection. For social intervention was not aimed at the poorest and most vulnerable as such, but those most threatening to order. $^{51}$

As governments and social philosophers were now increasingly speaking of the social whole they also distinguished the poor as a particular segment. This allowed distinct groups to be represented as posing a specific problem to be addressed through social policy while also signalling the mutual interests uniting all parts of society as a whole. In Castel's words, 'there is a direct connection between the idea of society as a

45 Gordon, Citizens without Sovereignty, p.240

46 Friedrich Engels, 'Preface to the English edition of 1888' in Karl Marx and Friedrich Engels, The Communist Manifesto (London: Penguin, [1888] 2002), p.202

47 Emanuel Adler, 'Seizing the Middle Ground: Constructivism in World Politics', European Journal of International Relations, Vol.3, no.3 (1997), pp.319-363; Alexander Wendt, 'On the Via Media: a Response to the Critics', Review of International Studies, Vol.26 (2000), pp.165-180

48 Karl Polanyi, The Great Transformation: The Political and Economic Origins of Our Time (Boston: Beacon Press, [1957] 2001), p.153; also see Gunnar Myrdal, The Political Element in the Development of Economic Theory (trans. Paul Streeten) (London: Routledge, 1953)

49 John Ruggie, Embedding Global Markets: an Enduring Challenge (Hampshire: Ashgate, 2008)

50 Moravcsik, 'Taking Preferences Seriously', p.527. This idea was extended to the period of post-World War II US hegemony and the rise of an American regulatory state during the New Deal. 'Just as the New Deal government increasingly took active responsibility for the welfare of the nation, US foreign policy planners took increasing responsibility for the welfare of the world'. Anne-Marie Burley, 'Regulating the World: Multilateralism, International Law, and the Projection of the New Deal Regulatory State' in John Ruggie (ed.) Multilateralism Matters: the Theory and Praxis of an Institutional Form (New York:

Columbia University Press, 1993), p.131

51 Mitchell Dean, The Constitution of Poverty: Toward a Genealogy of Liberal Governance (London: Routledge, 1991); Castel, From Manual Workers 
collection of interdependent parts and practical modes of intervention in that society'. ${ }^{52}$ Critiquing the logics of classical political economy and utilitarian philosophy, the founders of sociology insisted that norms, rules, and institutions are all 'social facts' requiring social, not individual, explanations. ${ }^{53}$ With the goal of sidestepping explicit ideological politics, pioneering sociologists offered a clearer scientific statement of the rules of sociological method. ${ }^{54}$ As the theorists of commercial sociability had shown, 'social' phenomena were not the product of sovereign will power. Hence sociological remedies to sociological problems were not found in conventional despotic power. Any meaningful transformation of society would not occur through repressive laws alone, but via the impersonal social environment itself: raison de la société not raison d'état. Hence the solution to anomie was to work on collective beliefs, creating new 'norms', to alter individual and collective behaviours. 'Between 1759', notes Rabinow, 'the date of the first appearance of the word normal, and 1834, the date of the first appearance of the word normalized, a normative class conquered the power to identify the function of social norms'. ${ }^{55}$ Social facts could be studied through the means of objective science and social problems were amenable to sociological remedies. Thus while offering a sociological explanation and solution for the multiple crises besetting capitalist and imperial order a non-ideological status was also bestowed on sociology. The particular way academic sociology sought to purge liberalism of ideology would be enormously significant for the way mainstream sociology was imported into international studies.

Consider George Herbert Mead's theory of symbolic interactionism, a central underpinning of Wendt's Social Theory of International Politics, and hence social constructivism more generally. ${ }^{56}$ One of the most influential American sociologists of the late-nineteenth and early twentieth-century, by his death in 1931 Mead had trained roughly 'half of all doctorial sociologists in the world' and wrote across the entire span of the Progressive Era of American history. ${ }^{57}$ Mead was critical of the quasi-social determinism of Comte, Spencer and Durkheim, conceiving the individual self as the product of a series of far more dynamic and evolving interactions with other selves. ${ }^{58}$ In the course of everyday life, rather than automatically respond to various gestures, individuals assigned meanings to the objects around them through a process of interpretation that was essentially symbolic, a form of meaningful interaction. ${ }^{59}$ Crucially,

52 Castel, From Manual Workers, p.270

53 Émile Durkheim, The Rules of Sociological Method and Selected Texts on Sociology and its Method (edited with an intro. by Steven Lukes) (trans. W. D. Halls) (London: Macmillan, 1982)

54 Szacki, 'Sociologism: Sociology as the Fundamental Social Science' in History of Sociological

Thought, chapter 10.

55 Paul Rabinow, French Modern: Norms and Forms of the Social Environment (Chicago: University of Chicago Press, 1989), p.10

56 Mead was highly influential on Peter L. Berger and Thomas Luckmann, The Social Construction of Reality: a Treaties in the Sociology of Knowledge (new edition) (London: Penguin, 1991)

57 Mary Jo Deegan, 'George Herbert Mead', in John Scott (ed.) Fifty Key Sociologists: the Formative

Theorists (London: Routledge, 2007), p.113

58 George H. Mead, Mind, Self and Society: from the Standpoint of a Social Behaviorist (edited and intro. by Charles W. Morris) (Chicago: University of Chicago Press, 1934)

59 In Wendt's formulation, 'the meanings an actor attributes to itself while taking the perspective of Others, while seeing itself as a social object... is a key link in the chain by which culture constitutes agents'. Wendt, Social Theory, p.182 
individuals become objects to their own selves as they take on different social roles, and they can cast their self into the position of significant others. In this process, individuals construct their behavior to produce a 'social self', coming to know what is expected of them in society. In Wendt's formulation, extended to relations between states, 'identities and their corresponding interests are learned and then reinforced in response to how actors are treated by significant Others... If the Other treats the Self as though she were an enemy, then... she is likely to internalize that belief in her own role identity vis-à-vis the Other' ${ }^{60}$ However, for Mead, human selfhood could progress to a stage in which individuals become conscious of realising social rules; they adopt the attitude of society as a whole and see beyond their self to actually embrace their role in society. Institutions - family, church, schools, etc. - instilled the ability to embrace the whole of society within an individual self, to adopt the position of and even positively embrace the 'generalized other'. In a democratic state, Mead argued, this embrace ought to be self-conscious, and even involve criticism of aspects of society.

Mead's theory was deeply practical. He explicitly asked how individuals could become social selves in a world defined by change and by the potential for revolutionary disorder. This was not an abstract question. As Mead was writing, American progressives were seeking to reform the worst excesses of industrial capitalism as an alternative to the more radical solutions workers were beginning to demand. ${ }^{61}$ This regulation of virtually every aspect of life - widely understood as a form of domestic engineering and social housekeeping - was guided by faith in the determined and professional 'human engineers' celebrated by Mead and other turn of the century sociologists. ${ }^{62}$ Mead's continuum between mind, self and society was his conscious attempt to provide the philosophical and sociological underpinnings to these Progressive Era reforms. ${ }^{63}$ 'How can you present order and structure in society and bring about the changes that need to take place...? ... That is the problem, to incorporate the methods of change into the order of society itself' ${ }^{64}$ For Mead, the answer was social control, which, he wrote, 'depends... upon the degree to which the individuals in society are able to assume the attitudes of the others who are involved with them in common endeavour' ${ }^{65}$ Social control was contingent on the degree of self control exhibited by members of society. Again, in Wendt's formulation, which he relates to international security communities, 'External constraints become internal constraints, so that social control is achieved primarily through self-

60 Wendt, Social Theory, p.327

61 Michael McGeer, A Fierce Discontent: The Rise and Fall of the Progressive Movement in America, 1870-1920 (New York: Oxford University Press, 2003)

62 As Mary Pattison claimed, homemaking 'could no longer be said to be a private undertaking. It is a public function, regulated and formulated by local and State authorities'. Mary Pattison, Principles of Domestic Engineering (New York, The Trow Press, 1915), p.248. Also see, for example, writing on 'sociocracy' by first President of the American Sociological Association, Lester F. Ward, Applied Sociology: a Treatise on the Conscious Improvement of Society by Society (Boston: Ginn \& Company, 1906)

63 Jane Addams, 'Problems of Municipal Administration', The American Journal of Sociology, Vol.10, no.4 (1905) pp.425-444

64 George Herbert Mead, 'The Problem of Society: How We Become Selves' in Movements of Thought in the Nineteenth Century (Chicago: University of Chicago Press, 1936), pp.361-362

65 George Herbert Mead 'The Genesis of Self and Social Control', International Journal of Ethics, Vol.35, no.3 (1925), p.275 
control'. ${ }^{66}$ Above all, members of society needed to understand what is expected, appropriate, and possible. Social science had an important and progressive role in this endeavour, developing and testing the methods by which humans could exhibit the necessary self control, increasing the chance that members of an ostensibly democratic polity would adopt the values and perform expected behaviours necessary for social order.

Ignoring fundamental relations of hierarchy and subordination, Mead dissolved society into a series of interactions because it helped to erase the sense of externality individuals experienced and were rebelling against in the increasingly imperial and industrial United States. From this perspective, Mead's updating of 'romantic organicism' ${ }^{97}$ for the distinctly American ends of 'self-improvement through personal change ${ }^{98}$ should primarily be of historic rather than scientific interest to international studies. Mead's symbolic interactionism tells us something about the purpose of sociology in a very specific, rebellious and politically charged, moment in American history. ${ }^{69}$ This history also tells us something about social theory in international politics. In symbolic interactionist mode, social constructivism purports to theorise how interstate conflict can be transformed if states adopt different mutual roles. ${ }^{70}$ In doing so, concepts such as interactionism, role taking, and the generalised Other are abstracted from the context in which they emerged and presented as contributions to methodological development in the language of the philosophy of social science and as a critique of the individualist assumptions of theories of rational choice. However, the essential contribution of such work was not primarily methodological, whether 'the study of ideas in international politics can be made scientifically respectable'. ${ }^{71}$ In contrast to the emphasis of Bartelson in this Forum, the most pressing problem was not the quest for a distinctive methodology to bestow scientific legitimacy. To a startling degree, social theories in this vein advanced through continual and concerted efforts to domesticate radical political action through 'socialisation', the effort to make populations 'social'.

But should all social theories be tarred with same brush? For Karl Lowith, 'social

66 Wendt, Social Theory, p.361

67 Dmitri N. Shalin, 'G. H. Mead, Socialism, and the Progressive Agenda' in Mitchell Aboulafia (ed.) Philosophy, Social Theory, and the Thought of George Herbert Mead (Albany, NY: State University of New York Press, 1991), p.48

68 Collins and Makowsky, The Discovery of Society, p.164

69 A few decades later, New Deal 'social security' reforms similarly countered socialism. After 1945, the language of security extended from social regulation and marched forth with the lexicon of national security, international security, human security and so on. For rare historical treatments of the expansion of security discourse see Mark Neocleous, 'From Social to National Security: on the Fabrication of Economic Order, Security Dialogue, Vol.37, no.3 (2006), pp.363-384 and Owens, 'Supreme Social Concept'.

$70 \mathrm{McCourt}$ has extended Mead's symbolic interactionism, arguing that 'foreign policymakers come to recognize the boundaries of acceptable and therefore possible action because social roles structure the interactions of states in international affairs in much the same way they do for individuals in everyday life... [S]tate leaders take the role of the Other in their international interactions: ...they view situations from the perspective of other states putting themselves in their shoes'. David M. McCourt, Britain and World Power since 1945: Constructing a Nation's Role in International Politics (Ann Arbor, MI: University of Michigan Press, 2014) p.14. Also see David M. McCourt, 'The Roles States Play: a Meadian Interactionist Approach', Journal of International Relations and Development, Vol.15 (2012), pp.370-392 71 Wendt, 'On the Via Media' 
science is not unified but divided into two: bourgeois sociology and Marxism' ${ }^{72}$ And for Martin Weber in this Forum, the legacy of critical social theory is indispensible since, to date, it has underpinned the best substantive account of the rise of capitalism and its relation to the state system. ${ }^{73}$ On this view, Marxist conflict theory is able to explain the origin and modes of antagonistic relations among groups and classes, the sources of 'social' conflict and change in international politics. Scholars working from within these more critical strands are thus at pains to stress that not all ways of conceiving the social have the same political, economic, and imperial implications. While some forms of social theorising have obscured the deeply hierarchical and imperial relations that characterise the world system others have drawn on distinctly social lexicons to produce precisely the opposite. Marxist thought and forms of socialist humanism have exposed bourgeois ideology and softened the worst aspects of the antagonism between capital and labour. So what difference does it make that Marx and subsequent traditions of critical theory adopted social language precisely to turn it against the ideologies that justified a new form of class rule? Critical theorists need a better way of parsing what they mean by 'social'. Despite the far greater attention to history in much critical international theory, it has too readily adopted social discourse, obscuring the proper history and ontology of social modes of governance and thought.

\section{Marx and Social Being}

Marxists - and political realists, of course - never fell for liberal versions of raison de la société. ${ }^{74}$ However, while abandoning almost every other element of bourgeois thought, Karl Marx grounded his critical science of capitalist development on several claims about the nature of society and social being. This was probably inevitable; 'the first criticism of any science necessarily finds itself under the influence of the premises of the science it is fighting against'. ${ }^{75}$ Socialism was already well established as the name for the collective ownership of the means of production; Europe's intellectual scene was completely under the sway of social language. ${ }^{76}$ By the middle of the nineteenth-century, analogies to the human body were irresistible with the near full incorporation of evolutionary theories from biology. ${ }^{77}$ The connection between society and life processes was not only in the sense of helping to establish the notion of a social whole in 'organicist sociology', ${ }^{78}$ but in

72 Karl Löwith, Max Weber and Karl Marx (London: Routledge, [1960] 1993), p.42

73 Martin Weber, 'On the History and Politics of the Social Turn', Review of International Studies, Vol.41, no.5 (2015), pp. [add at proof stage]

74 Again, due to limitations of space, we cannot examine in any detail realist defenders of raison d'état. However, in the words of Johann Caspar Bluntschli, 'The whole concept of society...is... a Third Estate concept, although we have grown used to the identifying the state itself with bourgeois society'. Quoted in Christoph Gödde, 'Editor's notes' in Theodor W. Adorno, Introduction to Sociology (Stanford, CA: Stanford University Press, 2000), p.164

75 Karl Marx, 'The Holy Family' in Selected Writings (edited by David McLellan) (revised edition) (Oxford: Oxford University Press, 2000), p.146. Marx was actually writing about Proudhon.

76 Pamela M. Pilbeam, French Socialists Before Marx: Workers, Women and the Social Question in France, 1796-1852 (Durham: Acumen Publishing, 2000)

77 Paul Heyer, Nature, Human Nature, and Society: Marx, Darwin, Biology, and the Human Sciences (Westport, CN: Greenwood Press, 1982)

78 Damiela Barberis, 'In Search of an Object: Organicist Sociology and the Reality of Society in Fin-desiècle France', History of the Human Sciences, Vol.16, no.3 (2003), pp.51-72 
Marx's much stronger sense of society as 'species-life itself'; humans were a 'speciesbeing' ${ }^{79}$ The supporting evidence seemed to be everywhere. The capitalist mode of production, underlying the organisation of bourgeois society, appeared like a natural biological force. As Marx and Engels observed,

The bourgeoisie, during its rule of scarce one hundred years, has created more massive and more colossal productive forces than have all proceeding generations together. Subjection of Nature's forces to man, machinery, application of chemistry to industry and agriculture, ...clearing of whole continents, ...whole populations conjured out of the ground - what earlier century had even a presentiment that such productive forces slumbered in the lap of social labour? ${ }^{80}$

Capitalism had released the masses from the feudal household and let loose the 'social' energies of the proletariat. Marx and his followers rightly condemned the discourse of burgerliche Gesellschaft as the rationalisation of class interests, but did not abandon the language of society and the social. Marx's belief in the progressive tendencies of capitalism, the idea that the seeds of the new order were necessarily and dialectically found in the old, led him to adopt several features of nineteenth-century social theory. He shared with this tradition a search for deeper 'social causes' for politics; a propensity toward grand teleological claims about the nature of historical development; belief that the emergence of both capitalism and the modern state destroyed feudal households; and faith in the introduction of radical new forms of social intervention to overcome alienation.

There are at least three ways in which the concepts of society and social are used in Marx's thought, all playing an important role in theorising in IR. First, and in agreement with the earliest social philosophers, Marx conceived society a set of material relations and 'social relations' of production; social life was the historically changing and yet fundamental base or foundation of political and legal institutions. One needed to understand the underlying social forces, a term first adopted by English social Darwinist Herbert Spencer, to comprehend the progress of human history. ${ }^{81}$ 'The relations of production in their totality', Marx wrote, 'constitute what are called the social relations, society, and specifically, a society at a definite stage of historical development, a society with a peculiar distinctive character. Ancient society, feudal society, bourgeois society are such totalities'. ${ }^{82}$ Again, the concept of totality was central to Marx's methodological effort to grasp the objective characteristics of historically evolving 'social' forms. Subsequent critical international political economists further pioneered the terminology of social forces as shorthand for the totality of relations produced by a particular mode of production. ${ }^{83}$ Social forces emanate from the production process; new social forces,

79 Karl Marx, The Marx-Engels Reader (edited by Robert C. Tucker) (New York: W.W. Norton, 1972), p. 41

80 Marx and Engels, The Communist Manifesto, pp.224-225

81 Floyd Nelson House, 'The Concept "Social Forces" in American Sociology', American Journal of Sociology, Vol. 31, no.2 (1925), pp.145-156.

82 Marx quoted in Stephen Henry Rigby, Marxism and History: a Critical Introduction (2nd edition) (Manchester: Manchester University Press, 1998), p.108

83 Robert W. Cox, Production, Power, and World Order: Social Forces in the Making of History (New York: Columbia University Press, 1987); for another early account of 'social forces' see Fred Halliday, 'A Necessary Encounter: Historical Materialism and International Relations' Rethinking International Relations (London: Macmillan, 1994), pp.47-73; 'Production is, in that sense, life, for the dispensation of 
states, and worlds orders are created through changes in the organisation of production. The term social formation also migrated from Marxist to realist IR with Robert Gilpin's revisions to Samir Amin's usage. ${ }^{84}$ Here, again, the type of social formation governs the generation, level and transfer of economic surplus, the distribution of wealth and power within and among states.

Marx obviously differed from the bourgeois theorists of 'social forms' in his rejection of autonomous individuals as both the origin and true heirs of the capitalist mode of production. "Above all, we must avoid postulating "society" again as an abstraction vis-à-vis the individual. The individual is the social being. His manifestations of life... are therefore an expression and confirmation of social life'. ${ }^{85}$ The notion of social relations as the underlying base of all else is closely related to Marx's second use of social and this, too, emerged out of enlightenment thought: humans make their world through secular, material interactions and these interactions - the social world they produce - require a social rather than individual or religious explanation. The modern conception of society was based on the idea of a differentiated and yet interconnected 'social whole'. Social theory purports to be a discourse about the structure of the social world as a whole, of the interdependence between groups in time and space. What better approach to knowledge production in IR? As Justin Rosenberg has put it, 'the intellectual requirements of social theory and international theory are - and always have been - one and the same' ${ }^{86}$ Both seek a general abstraction of the historical process and are deeply generalising. The world, for both, is an interconnected totality. Hence, following Marx's statement that society is the product of 'the sum of interrelations', ${ }^{87}$ Rosenberg has posited that the 'first principle of any strictly sociological method' in IR must be its 'fundamentally relational ontology'. ${ }^{88}$ Yet, even in its Marxist form, classical social theory is incomplete since it conceives of society in the singular. The task of a properly international historical sociology is to extend the basic premise of social theory to intersocietal relations, to offer a 'genuinely sociological definition' of the international ${ }^{89}$ In these increasingly influential formulations, the social is both the ontological reality of human existence and a field of knowledge production and method involving, as Durkheim would also have it, 'explanation not just of society but by society'. ${ }^{90}$ Surely,

energy (work) which results in life (product). "Social forces" was the identifiable social energy precipitated by production, the expenditure of which affected directly or indirectly the existing order'. Jeffrey Harrod, 'Social Forces and International Political Economy: Joining the two IRs', in Stephen Gill and James H. Mittleman (eds.) (Cambridge: Cambridge University Press, 1997), p.109

84 Samir Amin, Unequal Development: an Essay on the Social Formations of Peripheral Capitalisms (London: Monthly Review Press, 1976); Robert Gilpin, War and Change in International Politics (Cambridge: Cambridge University Press, 1981), p.108

85 Karl Marx, 'Economic and Philosophical Manuscripts of 1844', Collected Works, Vol.3 (Moscow: Progress Publishers, 1975), p. 229.

86 Rosenberg, 'Why there is no', p.336

87 Karl Marx, Grundrisse (trans. M. Nicolaus) (London: Penguin, 1973), p.265

88 Rosenberg, 'Why is there no', p.335 (emphasis added)

89 Rosenberg, 'Why is there no', p.308. For Rosenberg, Trotsky's notion of 'uneven and combined development' is just such a theory. See Justin Rosenberg, 'The "Philosophical Premises" of Uneven and Combined Development', Review of International Studies, Vol.39, no.3 (2013), pp.569-597.

90 Rosenberg, 'Why is there no', p.335. 
again, social discourse is indispensible for methodological reasons. ${ }^{91}$

But, of course, the sphere of self-instituted human relations is not the only or even primary sense in which Marx conceived of the social. In line with his belief in the progressive nature of capitalism, he wanted to celebrate and expand on the enlightenment 'discovery' of society. If humans were fundamentally social beings, a species being whose 'authentic existence is social activity and social satisfaction', then the social was also the source of human emancipation. 'By social', wrote Marx and Engels, 'we understand the co-operation of several individuals, no matter under what conditions, in what manner and to what end'. ${ }^{92}$ In this third and most radical meaning, the social stands for 'cooperative', the ability of humans to work together to move beyond older forms of exploitation and rule toward a new conception of the commons. Marx's philosophy of labour and history culminated in the goal of a 'socialised' or 'social' humanity. Although much critical international theory has shied away from explicit association with communism, Marx's claims regarding the need for universal emancipation has shaped one of its most important strands. ${ }^{93}$ Marx's powerful effort to subsume politics (collective human action to change the world) inside this version of the social (human cooperation ultimately grounded on exchange) upended the classical hierarchy between forms of life. ${ }^{94}$ 'The exchange of human activity within production itself as well as the exchange of human products with one another is equivalent to the generic activity and generic spirit whose actual, conscious, and authentic existence is social activity and social satisfaction'. ${ }^{95}$ The intention behind incorporating politics into the social-as-genericactivity was radical and even worthy. But, in doing so, Marx made a category error that the tradition of critical theory has yet to overcome. For in embracing social language as explanation and methodology Marx was unable to fully capture an essential - perhaps the essential - aspect of the rise and expansion of the social realm, its ontology, which makes the effort to incorporate politics into the social contradictory and self-defeating.

For what is this social realm inside which politics would be subsumed? What is the name, and what are the history and theory of this governance form? 'The bourgeoisie', Marx wrote with Engels, 'wherever it got the upper hand, has put an end to all feudal, patriarchal, idyllic relations' ${ }^{96}$ Marx joined Locke in supposing that the rise of contract societies in parts of Europe destroyed not only feudal households, but also household rule in general. Households - the dominant way of conceiving government prior to the rise of civil society - are the historically variable units of rule for the

91 In practice, social language usually ends up descriptive shorthand for something else, with scholars writing of global social change, social relations and practices and social institutions and processes, and particular social contexts. Jonathan Joseph, The Social in the Global: Social theory, Governmentality and Global Politics (Cambridge: Cambridge University Press, 2012)

92 Karl Marx and Friedrich Engels, The German Ideology (New York: International Publishers, 1970), p.50

93 Andrew Linklater, Beyond Realism and Marxism: Critical Theory and International Relations (London: Palgrave, 2000)

94 Nancy L. Schwartz, 'Distinction between Public and Private Life: Marx on the Zōon Politikon', Political Theory, Vol.7, no.2 (1979), pp.245-266; George E. McCarthy (ed.) Marx and Aristotle:

Nineteenth Century German Social Theory and Classical Antiquity (London: Rowman and Littlefield, 1992)

95 Karl Marx, 'Except-Notes of 1844', in Marx: Selected Writings (edited by Lawrence H. Simon) (Indianapolis, IN: Hackett, 1994), p.45

96 Marx and Engels, Communist Manifesto, p.222 
administration of life processes. ${ }^{97}$ Patriarchal, in Marx and Engels' formulation, refers to this theory of household government in which rule was modelled on the government of the family by the father as variously found in the ancient oikos, Roman households, feudal manors, royal households, empires as political households, all forms of despotism, early modern Polizeistaats, mercantilism, driot administrative, and cameralism. ${ }^{98}$ Yet, there is strong historical and theoretical evidence to suggest that the rise of contract society did not destroy large-scale forms of household rule. The rise of capitalist states scaled up and transformed household governance into a form of depersonalised bureaucratic despotism (from despot, master of the house). To be sure, in seeking to subsume politics inside the social Marx was reaching toward a political conception of the social, which is another way of saying that he was seeking to politicise the household. He sought emancipation in the distinctly modern, social form of household rule. But this is the arena for the domestication of conflict. This is why social theory advanced through varying attempts to explain and remedy revolts. It is the modern science of household rule, the science of how to domesticate those residing in the household. To be sure, Marx sought to dismantle the very distinction between household and politics that defined much of the tradition of political thought. ${ }^{99}$ The formerly political ability to act in concert to bring into being something new was to be located in the sphere of production; the possibility of the non-hierarchical administration of life processes remains, to say the least, unresolved. The problem is that in obscuring the household ontology of the actually existing social realm, Marx bequeathed to critical theory an inadequate vocabulary with which to capture the ontology of the social realm, as well as politics, and joined the tradition of social theory in confusing de-politicisation for methodological progress. ${ }^{100}$

\section{Conclusion: The New Science of Oikonomikos}

International theory has a social problem. Not in the late-nineteenth-century sense of the

97 For a small sample see F. Robert Hunter, Egypt under the Khedives, 1805-1879: from Household Government to Modern Bureaucracy (Pittsburgh, PA: University of Pittsburgh Press, 1984); Kate Mertes, The English Noble Household, 1250-1600: Good Governance and Politic Rule (Oxford: Blackwell, 1988); William James Booth, Households: on the Moral Architecture of the Economy (Ithaca, NY: Cornell University Press, 1993); David Herlihy, Medieval Households (Cambridge, MA: Harvard University Press, 1985); J. L McIntosh, From Heads of Household to Heads of State: the Preaccession Households of Mary and Elizabeth Tudor, 1516-1558 (New York: Columbia University Press, 2009); Suraiya Faroqhi, 'The Ottoman Empire: the age of 'political households' (eleventh-twelfth/seventeenth-eighteenth centuries)' in The New Cambridge History of Islam: Volume 2, The Western Islamic World, Eleventh to Eighteenth Centuries (Cambridge: Cambridge University Press, 2010), pp.366-410

98 Sir Robert Filmer, The Patriarcha and other political works of Sir Robert Filmer (edited by Peter Laslett) (New York: Transaction, 1984); Sir Henry Sumner Maine, 'The Patriarchal Theory', Quarterly Review, Vol.162 (1886), pp.181-209; Martin Riesebrodt, 'From Patriarchalism to Capitalism: the theoretical context of Max Weber's agrarian studies (1892-93)', in Keith Tribe (ed.) Reading Weber (London: Routledge, 1989) pp.131-154; Dubber, The Police Power

99 William James Booth, 'Politics and the Household: A Commentary on Aristotle's Politics, Book One', The History of Political Thought, Vol.2 (1981) pp.203-226

100 This also accounts for Marx's deeply contradictory writings on politics, which when translated into international theory, yield an inability to develop a compelling non-functionalist, non-realist conception of politics as an expression of force and violence. For an excellent account see Andrew Davenport, 'Marxism in IR: Condemned to a Realist Fate?' European Journal of International Relations, Vol.19 no.1 (2013) pp. $27-48$ 
heterogeneous crises related to family, health, education, housing, crime, and immigration arising from the system of wage labour and capitalist empires. ${ }^{101}$ The social problem of international theory is one of sociolatry, the celebration of social thought and the (often unwitting) rationalisation of distinctly social forms of governance. The point is not that sociologists have never said anything of interest, or that sociology is the only field with a problematic relation to the social. Nor is it to dispute the validity of philosophy of knowledge questions related to methodology, epistemology, and ontology. These philosophical questions preceded the formation of social science and it is not clear that distinctly social language is required to think seriously about them. Methodology matters, but it needs to be situated in a more historical and political analysis of the conditions under which seemingly methodological innovation occurs. In fact, the historical constellation in which the modern meanings of social and society were forged is far more significant - and interesting - than the philosophy of social science narrative suggests. To engage with this history poses a serious challenge to international theory for it concerns one of the most fundamental theoretical building blocks in the field. Without considering historical and political questions related to the rise of social discourse, rather than only philosophical or methodological ones, IR is unable to address whether the originary (methodological) narrative is misleading or even wrong. Yet, aside from a very small group of conceptual and intellectual historians, the recent 'historical turn in IR' 102 has come in one very particular form: international historical sociology. But this approach has largely eschewed an historical and ontological account of the rise of the social itself, including social forms of thought, and is currently ill-equipped to offer this history. It relies on the conventions of social theory.

But what exactly is wrong with the way international studies has turned to social thought? Jens Bartelson in this Forum addresses the simple problem of ahistoricity and anachronism. Intended to serve specific and contingent purposes in a particular historical context, the resultant concept of society has been repeated in international theory and then projected into locations where it does not make sense. But, in theory at least, this problem could be overcome if scholars were more attentive to the historicity of their concepts. Bartelson and Weber criticise the way IR has unwittingly incorporated functionalism and social evolutionism into international theory or projected Eurocentric concepts onto alien historical and cultural contexts. But they conclude that IR simply needs less Eurocentric and more conflict-oriented social theories. To be sure, that concepts have history is not reason enough for abandoning them. The question is whether in light of this history they remain appropriate for their particular object of study. Hence, it could be argued that because social discourse emerged in parallel with the rise of capitalist nation-states it is precisely the language for analysing these states and their interrelations. On this view, social theories are needed precisely because of the history of social thought, not in spite of it. Yet, this partial criticism (and defense) of social theory is not grounded on analysis of what the social realm actually is, the modern form of household rule. There is a more fundamental problem than ahistoricity and anachronism. Distinctly social forms of governance have history; they also have ontology and politics.

101 John A. Hobson, The Social Problem: Life and Work (London: James Nisbet, 1901)

102 Thierry Lapointe and Frèdérick Guillaume Dufour, 'Assessing the Historical Turn in IR: an Anatomy of Second Wave Historical Sociology', Cambridge Review of International Affairs, Vol.25, no.1 (2012), pp. $97-121$ 
The analysis in this contribution to the Forum suggests that the gravest problem with the ahistorical social in international thought is that it obscures analysis of the governance form of which the modern social realm is an expression. Consider again why and with what significance social thought was first enveloped inside a discourse about commercial society and then bourgeois civil society in a period of expanding European empires. The clue is in how the rise of a new and revolutionary discourse about human relations emerged with a new and revolutionary way of managing life processes. As we have seen, the management of life took on new forms with the rise of the social realm, the intermediary between modern states and capital, and received its most powerful rationalisation through the language of civilised society and social philosophy. Another clue is that central to early liberalism was the explicit effort to displace despotic power among autonomous individuals with an image of government as a freely chosen contract. Civil society discourse explicitly targeted the notion of government-as-household, at least among self-governing citizens. ${ }^{103}$ Yet contra Locke and indeed Marx, the rise of modern contract societies did not put an end to household forms of rule and thought. ${ }^{104}$ They scaled up and transformed them. Above all, personalist authority was largely replaced by bureaucratic administration, that is, depersonalised despotic 'no man rule'. ${ }^{105}$ This is why social theory advanced at the expense of different forms of 'politics' but in the guise of methodological advance. As witnessed in sociability discourse, the Social Question, theories of socialisation, and even Marx's effort to subsume politics inside the social, social theory is the modern science of oikonomikos, from the Greek oikos for household, the science of how to rule over, depoliticise, and domesticate those residing in the household. ${ }^{106}$

If this analysis of social theory is correct, and much more research is required, then we would no longer need a social theory of international relations. We would need to develop a history and theory of the modern social realm as a distinctly modern, capitalist and imperialist form of household. Thus the claim is not that all uses of social terminology are necessarily tarnished. This cannot be the argument since, as suggested throughout this article there are processes and relations that are usefully understood as social. The social realm exists and it should be described as such. However, analysis of distinctly social forms of governance and thought should be understood as the modern and capitalist variant on the science and practice of household rule. What is actually at stake in the historicity of the social remains an open question until more historical and theoretical work has been done. It is certain that without an adequate historical and

103 Yvonne Chiu and Robert S. Taylor 'The Self-Extinguishing Despot: Millian Democratization', The Journal of Politics, Vol.73, no.4 (2011), pp.1239-1250. C.f. Carole Pateman, The Sexual Contract (Cambridge: Polity, 1998); Mariana Valverde, “'Despotism” and Ethical Liberal Governance', Economy and Society, Vol.25, no.3 (1996), pp.357-372

104 Foucault's influential account of the 'discovery of population' identified the family as model of government that was eliminated with the rise of 'society'. Hence, alongside the common conflation of household and family, Foucault and his followers were unable to identify how populations were governed through new household forms of rule. Michel Foucault, Security, Territory, Population: Lectures at the Collège de France, 1977-1978 (edited by Michel Senellart) (trans. by Graham Burchell) (London: Palgrave, 2007), p.71

105 Arendt, Human Condition, p.40; Jennifer Ring, 'On Needing Both Marx and Arendt: Alienation and the Flight from Inwardness', Political Theory, Vol.17, no.3 (1989), pp.432-448

106 Xenophon, Memorabilia, Oeconomicus, Symposium and Apology (Cambridge, MA: Harvard University Press, 1923) 
political account of the rise of the social and distinctly social thought international studies is unable to understand the real meaning and potential worth of the original 'social turn'. 